\title{
Characterization of Selective Antibacterial Peptides by Polarity Index
}

\author{
C. Polanco, ${ }^{1,2}$ J. L. Samaniego, ${ }^{3}$ T. Buhse, ${ }^{1}$ F. G. Mosqueira, ${ }^{4}$ A. Negron-Mendoza, ${ }^{5}$ \\ S. Ramos-Bernal, ${ }^{5}$ and J. A. Castanon-Gonzalez ${ }^{2}$
}

${ }^{1}$ Centro de Investigaciones Químicas, Universidad Autónoma del Estado de Morelos, Avenida Universidad 1001, 62209 Cuernavaca, MOR, Mexico

${ }^{2}$ Subdireccion de Epidemiologia Hospitalaria y Control de Calidad de la Atencion Medica, Instituto Nacional de Ciencias Medicas y Nutricion Salvador Zubiran, Vasco de Quiroga 15, Piso 4, Colonia Seccion XVI, 14000 Mexico City, DF, Mexico

${ }^{3}$ Departamento de Matematicas, Facultad de Ciencias, Universidad Nacional Autonoma de México, Ciudad Universitaria, 04510 Mexico City, DF, Mexico

${ }^{4}$ Direccion General de Divulgacion de la Ciencia, Universidad Nacional Autonoma de Mexico, Ciudad Universitaria, P.O. Box 70487, 04510 Mexico City, DF, Mexico

${ }^{5}$ Instituto de Ciencias Nucleares, Universidad Nacional Autonoma de México, Ciudad Universitaria, P.O. Box 70543, 04510 Mexico City, DF, Mexico

Correspondence should be addressed to C. Polanco, polanco@unam.mx

Received 16 December 2011; Revised 18 January 2012; Accepted 19 January 2012

Academic Editor: Jean-Marie Zajac

Copyright (c) 2012 C. Polanco et al. This is an open access article distributed under the Creative Commons Attribution License, which permits unrestricted use, distribution, and reproduction in any medium, provided the original work is properly cited.

\begin{abstract}
In the recent decades, antibacterial peptides have occupied a strategic position for pharmaceutical drug applications and became subject of intense research activities since they are used to strengthen the immune system of all living organisms by protecting them from pathogenic bacteria. This work proposes a simple and easy statistical/computational method through a peptide polarity index measure by which an antibacterial peptide subgroup can be efficiently identified, that is, characterized by a high toxicity to bacterial membranes but presents a low toxicity to mammal cells. These peptides also have the feature not to adopt to an alpha-helicoidal structure in aqueous solution. The double-blind test carried out to the whole Antimicrobial Peptide Database (November 2011) showed an accuracy of $90 \%$ applying the polarity index method for the identification of such antibacterial peptide groups.
\end{abstract}

\section{Introduction}

The increasing resistance of pathogen agents towards multiple drugs has oriented parts of the investigation in bioinformatics to fast and efficient techniques that can predict the remarkable impact of antibacterial peptide action. These techniques can help to enhance the sometimes cumbersome chemical synthetic approach as well as the subsequent trial and error experiments to identify the peptide performance.

Among the proposed various classifications of peptides, one of it refers to the alpha-helicoidal versus beta-sheet conformation that the peptides can adopt in aqueous solution. This classification refers to the predominance of certain amino acids in the linear sequence of the peptides such as proline-arginine, cathelicidin, or cysteine. It is important to note that such classification appears to be without any influence on the toxicity or selectivity of the peptide once it got in contact with the target membrane $[1,2]$.

Although nature was used as the main source of peptides with antibacterial properties in the past [3], parts of the research efforts are now more directed towards synthetic strategies. One of these synthetic approaches generate the peptides by replacing and/or removing constitutive amino acids from a natural peptide known for its antibacterial action [4], thus trying to reduce its size while keeping or increasing its toxicity [5]. Another technique consists of joining two peptides that individually do not exhibit antibacterial properties but combined turn out to be highly toxic [6].

To obtain efficient antibacterial peptides by measuring the potential action of each altered peptide with the-above 
described methods would result in a possibility combination that exceeds by far the capacity of the known verification methods in the laboratory. For instance, the number of possible peptides to be formed from one peptide with 8 amino acids in length would be $20^{8}=25,600,000,000$ peptides. This is the reason why contemporary technique profiles to construct antibacterial peptides are the result of joint computational and/or mathematical methods to simulate peptide variations and then to evaluate and qualify these variations to eventually determine if the peptide complies with the required purposes. However, these methods with the aim to simulate the properties of the peptides as well as to evaluate their performance respecting all possible combinatorics are highly complex in their mathematical/computational model design.

In this paper, we present a statistical method that can be attributed to a single physical-chemical property, which is easy to computerize and that efficiently identifies antibacterial peptide subgroups for its highly selective toxicity to bacteria, hereinafter referred to as "Selective Cationic Amphipathic Antibacterial Peptides" (SCAAPs). A SCAAP is characterized by being less than 60 amino acids in length, not adopting an alpha-helicoidal structure in neutral aqueous solution, and showing a therapeutic index higher than 75 [7]. The therapeutic index of a peptide is defined as the ratio between the minimum inhibitory concentration observed against mammalian and bacterial cells $[7,8]$; that is, the higher the value, the more specific the peptide for bacteriallike membranes. Hence SCAAPs display strong lytic activity against bacteria but exhibit no toxicity against normal eukaryotic cells such as erythrocytes [9].

Our method determines an index that we call polarity index that uses the existent 20 proteic amino acid classification differentiated by its side chain $\mathrm{R}$ that divides them in four types and three categories [10]. The three general categories of side chains are nonpolar, polar but uncharged, and charged polar. The nonpolar residues include those with aliphatic hydrocarbon side chains: Gly, Ala, Val, Leu, Ilu, Pro, one aromatic group, Phe, and one "pseudo-hydrocarbon," Met. The polar but neutral category contains two hydroxylcontaining residues, Ser and Thr; two amides, Asn and Gln; two with aromatic rings, Tyr and Trp; one with a sulfhydryl group, Cys. In the charged polar class there are two amino acids with acidic groups, Asp and Glu, and three bases, His, Lys, and Arg (Table 1). The polarity index only makes use of that classification to get the SCAAP characteristic blueprint that in a double-blind test applied to all known peptides registered in the APD database (November 2011) [11] showed a very high efficiency.

\section{Methods}

2.1. Physicochemical Properties. Peptides can be expressed linearly as an amino acid sequence [12]. Such representation gives the peptide a unique blueprint. From this sequence, mathematical/computational algorithms have been designed with different complexity levels that measure a variety of physicochemical properties [13]. Among the properties on which the linear peptide representation focuses are two that
TABLE 1: 20 proteinogenic amino acid classification differentiated by their side chain according to their polarity [10].

\begin{tabular}{lcc}
\hline Symbol & Category & 1-letter code \\
\hline $\mathrm{P}-$ & polar & $\mathrm{D}, \mathrm{E}, \mathrm{Y}$ \\
$\mathrm{N}$ & neutral & $\mathrm{C}, \mathrm{G}, \mathrm{N}, \mathrm{Q}, \mathrm{S}, \mathrm{T}$ \\
$\mathrm{P}+$ & basic hydrophilic & $\mathrm{H}, \mathrm{K}, \mathrm{R}$ \\
$\mathrm{NP}$ & non polar residues & A, F, I, L, M, P, V, W \\
\hline
\end{tabular}

define if a peptide falls into the category of SCAAP [7]; that is, when its measure meets simultaneously the parameters established for the following physicochemical properties:

(i) isoelectric point [14] (IP) from 9.65 to 11.80 ,

(ii) hydrophobic moment [14] (HM) from 0.16 to 0.57 .

Note that the original parameter values [7] have been extended. For this work, it was decided to take these two properties at a maximum range without considering the so-called AGADIR property, which is the tendency for not adopting an alpha-helicoidal structure in aqueous solution. As we have already verified [13], this property is not of significance for peptides with a length smaller than 22 amino acids.

A statistical-computational method was designed based only on one physicochemical property: polarity, which quickly and efficiently discerns if a peptide falls into the category of SCAAP or not. The verification was carried out by evaluating the IP and HM physicochemical properties.

2.2. Polarity Index Method. The polarity index method uses the 20 amino acid classification differentiated by their side chains that fall into four polarity groups: $[\mathrm{P}+]$ polar, $[\mathrm{N}]$ neutral, $[\mathrm{P}+]$ basic hydrophilic, and $[\mathrm{NP}]$ nonpolar residues (Table 1).

From these four groups, a polarity $\mathbf{P}[i, j]$ matrix is built with 16 elements that have as rows and columns the four different polarity groups set in the order $\mathrm{P}+, \mathrm{P}-, \mathrm{N}, \mathrm{NP}$ and where $\mathbf{P}[i, j]$ matrix elements $[i, j]$ represent the 16 possible interactions of the groups.

The method consists of the following steps.

(i) Creating a $\mathbf{P}[i, j]$ incidence matrix from the subject peptide.

(ii) Generating a $\mathbf{Q}[i, j]$ incidence matrix from the SCAAP set.

(iii) Comparing the incidences from both $\mathbf{P}[i, j]$ and $\mathbf{Q}[i, j]$ matrices.

2.3. $\mathbf{P}[i, j]$ Incidence Matrix from a Subject Peptide. The $\mathbf{P}[i, j]$ incidence matrix is built by adding to each of its elements the matches that occurred in the peptide subject sequence from the left to the right with two amino acids in length and by moving one amino acid to the right at the time until it arrives at the peptide side end. Each amino acid pair is related to its polarity group. From that association, we identify row $i$ and column $j$. To the $\mathbf{P}[i, j]$ matrix element 
TABLE 2: SCAAP subjects [7]. IP: estimated isoelectric point. HM: hydrophobic moment. TI: calculated therapeutic index. Peptides Cecropin$\mathrm{A}$ and $\mathrm{CA}(1-8) \mathrm{M}(1-18) \mathrm{NH} 2$ were used to determine the $\mathrm{P}[i, j]$ incidence matrix.

\begin{tabular}{|c|c|c|c|c|c|}
\hline Entry & Peptide & Sequence & IP & HM & TI \\
\hline 1 & $(\mathrm{KIAKKIA}) 2 \mathrm{NH} 2$ & KIAKKIAKIAKKIA & 11.5 & 0.48 & 86.2 \\
\hline 2 & (KLGKKLG)3NH2 & KLGKKLGKLGKKLGKLGKKLG & 11.7 & 0.49 & 98.3 \\
\hline 3 & Cecropin-A & KWKLFKKIEKVGQNIRDGIIKAGPAVAVVGQATQIAK & 11.2 & 0.44 & 1000.0 \\
\hline 4 & Melittin & GIGAVLKVLTTGLPALISWIKRKRQQ & 12.6 & 0.46 & 500.0 \\
\hline 5 & Magainin 2 & GIGKFLHSAKKFGKAFVGEIMNS & 10.8 & 0.56 & 75.0 \\
\hline 6 & $\mathrm{CA}(1-13) \mathrm{M}(1-13) \mathrm{NH} 2$ & KWKLFKKIEKVGQGIGAVLKVLTTGL & 11.1 & 0.53 & 400.0 \\
\hline 7 & $\mathrm{CA}(1-8) \mathrm{M}(1-18) \mathrm{NH} 2$ & KWKLFKKIGIGAVLKVLTTGLPALIS & 10.4 & 0.43 & 2000.0 \\
\hline
\end{tabular}

TABLE 3: Number of matches in a typical SCAAP sequence in each peptide database with single or multiple action on fungi, viruses, mammalian cells, Gram+/Gram- bacteria, cancer cells, insects, parasites, and sperms (see also Section 2.6) [7].

\begin{tabular}{lccccccccc}
\hline Total & Action & Fungi & Viruses & Mammalian cells & Bacteria & Cancer cells & Insects & Parasites & Sperms \\
\hline 879 & Unique & $0 / 77$ & $0 / 22$ & $0 / 10$ & $51 / 743$ & $1 / 16$ & $0 / 2$ & $0 / 9$ & $0 / 0$ \\
2644 & Multiple & $62 / 638$ & $7 / 122$ & $20 / 205$ & $76 / 1489$ & $21 / 121$ & $3 / 20$ & $5 / 40$ & $1 / 9$ \\
\hline
\end{tabular}

will be added 1 , resulting thus in $\mathbf{P}[i, j]=\mathbf{P}[i, j]+1$. Finally, the $\mathbf{P}[i, j]$ incidence matrix relative frequency distribution is normalized and weighted over a 0.30 factor. This last step helps to enhance the peptide distinctive characteristics by increasing the effect of the relative frequency position of the amino acids pairs in the incidence matrix $\mathbf{P}[i, j]$.

2.4. $\mathbf{Q}[i, j]$ Incidence Matrix from a SCAAP Set. The $\mathbf{Q}[i, j]$ incidence matrix is determined following the same procedure as for the $\mathbf{P}[i, j]$ incidence matrix. The peptide used here is the set of peptide sequences described in Table 2. The peptides used here as SCAAP templates were reported as SCAAP subjects by Del Rio et al. [7]. From the 7 peptides submitted, only those with a therapeutic index higher or equal to 1000 were chosen (Table 2, entries 3 and 7).

2.5. $\mathbf{P}[i, j]$ and $\mathbf{Q}[i, j]$ Matrices Comparison. In both the $\mathbf{P}[i, j]$ and the $\mathbf{Q}[i, j]$ matrices five stated positions $\mathbf{M}_{1}$, $M_{2}, M_{3}, M_{4}$, and $M_{16}$ were identified, where the subscript numeral stands for the element position in the matrix. The first row in the matrix represents the first four positions, the second row the next four positions, and so forth until allocating the last four positions to the last row. The position of the four elements with higher incidence would be $M_{1}$, $M_{2}, M_{3}$, and $M_{4}$ while $M_{16}$ being the one with the lowest incidence. If the sequences $\left\{M_{1}, M_{2}, M_{3}, M_{4}, M_{16}\right\}$ for both matrices coincide, the peptide is classified as SCAAP.

2.6. Trial Data Preparation. 1894 peptides registered in the Antimicrobial Peptide Database (APD) [11] (November 2011) were analyzed and classified by their single and multiple action against fungi, virus, mammalian cells, Gram+/Gram - bacteria, cancer cells, insects, parasites, and sperms. Peptides with more than one action were not included. The single action database only includes peptides with confirmed experimental action on a single pathogen agent, in contrast to multiple-action databases that contain peptides with action on two or more pathogen agents. On this basis, the figures in multiple action databases are overrepresented.

The verification of peptides found in the single-action database on Gram+/Gram- bacteria was carried out by validating both the isoelectric point (IP) and hydrophobic moment (HM) in the ranges stated (see Section 2.1). The integrity of the APD database information was verified by checking identified peptides by their action in the whole extent of the database itself.

\section{Results}

Due to the importance of detecting possible peptide pathogenic action, the use of computer programs that evaluate peptic sequences to predict their action on different pathogen agents such as fungi, virus, mammalian cells, and Gram+/Gram- bacteria has become a standard practice among different research groups. The polarity index method is one of these computer programs, but it differs in measuring exclusively one physicochemical property to identify a SCAAP.

The $\mathbf{P}[i, j]$ Incidence matrix delivered by the polarity index method to identify a SCAAP used two peptides known by their toxic activity on Gram+/Gram+ bacteria (Table 2, entries 3 and 7$)$ that turned out to be $\left\{M_{1}, M_{2}, M_{3}\right.$, $\left.\mathrm{M}_{4}, \mathrm{M}_{16}\right\}=\{16,4,13,15,10\}$. SCAAP subjects identified from the provided single pathogenic action peptide database were fungi $(0 / 77)$, viruses $(0 / 22)$, mammalian cells $(0 / 10)$, Gram+/Gram+ bacteria (51/743), cancer cells (1/16), insects $(0 / 2)$, parasites $(0 / 9)$, and sperms $(0 / 0)$ (Table 3$)$.

Note that the polarity index method only identified SCAAP subjects basically in the bacterial group. Whereas SCAAP subjects identified from the multiple pathogenic action peptide database were fungi (62/638), viruses (7/122), mammalian cells (20/205), Gram+/Gram+ bacteria (76/1489), cancer cells (21/121), insects (3/20), parasites (5/40), and sperms (1/9) (Table 3). Among the 743 peptides with a single action on Gram+/Gram- bacteria, the polarity index method identified 51 SCAAP subjects (Table 4), their 
TABLE 4: SCAAP subjects identified by the polarity index method in APD Gram+/Gram - bacteria database [11] where peptides have action only on bacteria. IP: estimated isoelectric point. HM: hydrophobic moment. Status: (X) not accepted for its IP and HM parameters, because the corresponding calculations were out of the ranges [7] (see Section 2.1).

\begin{tabular}{|c|c|c|c|c|c|c|}
\hline No. & Peptide & Sequence & IP & HM & Status & Reference \\
\hline 1 & $\begin{array}{l}\text { Clavanin D (sea squirt, tunicate, } \\
\text { invertebrates, animals) }\end{array}$ & AFKLLGRIIHHVGNFVYGFSHVF & 10.85 & 0.54 & & {$[21]$} \\
\hline 2 & $\begin{array}{l}\text { Palustrin-1b (frog, amphibians, } \\
\text { animals; XXU) }\end{array}$ & ALFSILRGLKKLGNMGQAFVNCKIYKKC & 10.80 & 0.49 & & {$[22]$} \\
\hline 3 & $\begin{array}{l}\text { Palustrin-1d (frog, amphibians, } \\
\text { animals; XXU) }\end{array}$ & ALSILKGLEKLAKMGIALTNCKATKKC & 10.50 & 0.35 & & {$[22]$} \\
\hline 4 & $\begin{array}{l}\text { Palustrin-1c (frog, amphibians, } \\
\text { animals; XXU) }\end{array}$ & ALSILRGLEKLAKMGIALTNCKATKKC & 10.60 & 0.35 & & {$[22]$} \\
\hline 5 & $\begin{array}{l}\text { Brevinin-1PRc (frog, amphibians, } \\
\text { animals; XXU) }\end{array}$ & FFPMLAGVAARVVPKVICLITKKC & 10.50 & 0.38 & & {$[23]$} \\
\hline 6 & $\begin{array}{l}\text { Brevinin-1Be (frog, amphibians, } \\
\text { animals; XXU) }\end{array}$ & FLPAIVGAAAKFLPKIFCVISKKC & 10.30 & 0.43 & & {$[24]$} \\
\hline 7 & $\begin{array}{l}\text { Brevinin-1HSa (frog, amphibians, } \\
\text { animals; XXU) }\end{array}$ & FLPAVLRVAAKIVPTVFCAISKKC & 10.50 & 0.40 & & {$[25]$} \\
\hline 8 & $\begin{array}{l}\text { Brevinin-1Ba (frog, amphibians, } \\
\text { animals; XXU) }\end{array}$ & FLPFIAGMAAKFLPKIFCAISKKC & 10.30 & 0.50 & & {$[24]$} \\
\hline 9 & $\begin{array}{l}\text { Brevinin-1Bc (frog, amphibians, } \\
\text { animals; XXU) }\end{array}$ & FLPFIAGVAAKFLPKIFCAISKKC & 10.30 & 0.49 & & {$[24]$} \\
\hline 10 & $\begin{array}{l}\text { RANATUERIN } 4 \text { (ranatuerin-4, frog, } \\
\text { amphibians, animals; XXU) }\end{array}$ & FLPFIARLAAKVFPSIICSVTKKC & 10.50 & 0.46 & & {$[26]$} \\
\hline 11 & $\begin{array}{l}\text { Phylloseptin-H11 (PLS-H11, } \\
\text { Phylloseptin-13, PS-13; frog, } \\
\text { amphibians, animals; XXA) }\end{array}$ & FLSLIPHAINAVGVHAKHF & 9.65 & 0.36 & & {$[27]$} \\
\hline 12 & $\begin{array}{l}\text { Phylloseptin-H5 (phylloseptin-7, } \\
\text { PLS-H5, PS-7, XXA, frog, amphibians, } \\
\text { animals) }\end{array}$ & FLSLIPHAINAVSAIAKHF & 9.65 & 0.45 & & {$[28]$} \\
\hline 13 & $\begin{array}{l}\text { Phylloseptin-H2 (PLS-H2, } \\
\text { Phylloseptin-2, PS-2) (XXA, frog, } \\
\text { amphibians, animals) }\end{array}$ & FLSLIPHAINAVSTLVHHF & 7.80 & 0.46 & $\mathrm{X}$ & {$[29]$} \\
\hline 14 & $\begin{array}{l}\text { Phylloseptin-B1 (PLS-B1, PBN1; frog, } \\
\text { amphibians, animals; XXA) }\end{array}$ & FLSLIPHIVSGVAALAKHL & 9.65 & 0.46 & & {$[30]$} \\
\hline 15 & $\begin{array}{l}\text { Papilosin (tunicate, ascidian, } \\
\text { invertebrates, sea animals) }\end{array}$ & GFWKKVGSAAWGGVKAAAKGAAVGGLNALAKHIQ & 11.40 & 0.32 & & {$[31]$} \\
\hline 16 & $\begin{array}{l}\text { SMAP-34 (sheep myeloid } \\
\text { antimicrobial peptide- } 34 \text {; OaMAP } 34 \text {, } \\
\text { ovine cathelicidin, sheep, ruminant, } \\
\text { animals) }\end{array}$ & GLFGRLRDSLQRGGQKILEKAERIWCKIKDIFR & 10.43 & 0.48 & & {$[32]$} \\
\hline 17 & $\begin{array}{l}\text { Caerin } 1.17 \text { (frog, amphibians, } \\
\text { animals; XXA) }\end{array}$ & GLFSVLGSVAKHLLPHVAPIIAEKL & 9.50 & 0.49 & & {$[33]$} \\
\hline 18 & $\begin{array}{l}\text { Caerin } 1.18 \text { (frog, amphibians, } \\
\text { animals; XXA) }\end{array}$ & GLFSVLGSVAKHLLPHVVPVIAEKL & 9.50 & 0.50 & & {$[33]$} \\
\hline 19 & $\begin{array}{l}\text { Fallaxidin } 3.2 \text { (XXA, frog, amphibians, } \\
\text { animals) }\end{array}$ & GLLDFAKHVIGIASKL & 9.50 & 0.49 & & {$[34]$} \\
\hline 20 & $\begin{array}{l}\text { Fallaxidin } 3.1 \text { (XXA, frog, amphibians, } \\
\text { animals) }\end{array}$ & GLLDLAKHVIGIASKL & 9.50 & 0.48 & & {$[34]$} \\
\hline 21 & $\begin{array}{l}\text { Dahlein } 5.2 \text { (frog, amphibians, } \\
\text { animals) }\end{array}$ & GLLGSIGNAIGAFIANKLKPK & 11.10 & 0.52 & & {$[35]$} \\
\hline 22 & $\begin{array}{l}\text { Caerin } 1.2 \text { (XXA, frog, amphibians, } \\
\text { animals) }\end{array}$ & GLLGVLGSVAKHVLPHVVPVIAEHL & 7.02 & 0.49 & $\mathrm{X}$ & {$[36]$} \\
\hline
\end{tabular}


Table 4: Continued.

\begin{tabular}{|c|c|c|c|c|c|}
\hline No.Peptide & Sequence & IP & $\mathrm{HM}$ & Status & Reference \\
\hline $\begin{array}{l}\text { Caerin } 1.4 \text { (XXA, frog, amphibians, } \\
\text { animals) }\end{array}$ & GLLSSLSSVAKHVLPHVVPVIAEHL & 7.02 & 0.48 & $\mathrm{X}$ & {$[36]$} \\
\hline $\begin{array}{l}\text { Palustrin-2SIb (frog, amphibians, } \\
\text { animals; XXU) }\end{array}$ & GLWNSIKIAGKKLFVNVLDKIRCKVAGGCKTSPDVE & 10.10 & 0.36 & & {$[37]$} \\
\hline $\begin{array}{l}\text { XPF (the xenopsin precursor } \\
25 \text { fragment, African clawed frog, } \\
\text { amphibians, animals) }\end{array}$ & GWASKIGQTLGKIAKVGLKELIQPK & 11.00 & 0.40 & & {$[38]$} \\
\hline 26 Pleurocidin (fish, animals) & GWGSFFKKAAHVGKHVGKAALTHYL & 11.00 & 0.34 & & {$[39]$} \\
\hline $\begin{array}{l}27 \text { Cecropin (insects, invertebrates, } \\
\text { animals) }\end{array}$ & GWLKKIGKKIERVGQNTRDATVKGLEVAQQAANVAATVR & 11.30 & 0.36 & & {$[40]$} \\
\hline $\begin{array}{l}\text { Pm_mastoparan PMM (insects, } \\
28 \text { invertebrates, animals; XXA; } \\
\text { derivatives) }\end{array}$ & INWKKIASIGKEVLKAL & 10.80 & 0.37 & & {$[41]$} \\
\hline $29 \begin{array}{l}\text { Hinnavin II (Hin II, insects, } \\
\text { invertebrates, animals; JJsn) }\end{array}$ & KWKIFKKIEHMGQNIRDGLIKAGPAVQVVGQAATIYKG & 10.12 & 0.45 & & {$[42]$} \\
\hline $\begin{array}{l}\text { Ostrich AvBD2 (Ostrich avian beta } \\
30 \text { defensin 2, ostricacin-1, OSP-1, birds, } \\
\text { animals; BBL) }\end{array}$ & LFCRKGTCHFGGCPAHLVKVGSCFGFRACCKWPWDV & 8.94 & 0.33 & $\mathrm{X}$ & {$[43]$} \\
\hline $\begin{array}{l}\text { Clavanin D (sea squirt, tunicate, } \\
\text { invertebrates, animals) }\end{array}$ & LFKLLGKIIHHVGNFVHGFSHVF & 10.80 & 0.56 & & {$[44]$} \\
\hline $\begin{array}{l}\text { Enterocin Q (EntQ, class 2d } \\
32 \text { bacteriocins; leaderless, that is, no } \\
\text { signal peptide, bacteria) }\end{array}$ & MNFLKNGIAKWMTGAELQAYKKKYGCLPWEKISC & 10.00 & 0.39 & & {$[45]$} \\
\hline $\begin{array}{l}\text { Temporin-1Lb (Temporin } 1 \mathrm{Lb} \text {, frog, } \\
\text { amphibians, animals) }\end{array}$ & NFLGTLINLAKKIM & 10.80 & 0.41 & & {$[24]$} \\
\hline $34 \begin{array}{l}\text { Bovine beta-defensin } 6 \text { (bBD- } 6 \text {,cow, } \\
\text { ruminant, animals) }\end{array}$ & $\begin{array}{l}\text { QGVRNHVTCRIYGGFCVPIRCPGRTRQIGTCFGRPVKCC- } \\
\text { RRW }\end{array}$ & 11.30 & 0.37 & & {$[46]$} \\
\hline $35 \begin{array}{l}\mathrm{mBD}-4 \text { (mBD4, mouse beta-defensin } \\
\text { 4, or Defb4, animals; } 3 \mathrm{~S}=\mathrm{S})\end{array}$ & QIINNPITCMTNGAICWGPCPTAFRQIGNCGHFKVRCCKIR & 8.91 & 0.33 & $\mathrm{X}$ & {$[47]$} \\
\hline $\begin{array}{l}\text { ChBac5 (Pro-rich; Arg-rich, goat } \\
\text { cathelicidin, ruminant, animals) }\end{array}$ & RFRPPIRRPPIRPPFNPPFRPPVRPPFRPPFRPPFRPPIGPFP & 13.45 & 0.50 & & {$[48]$} \\
\hline $\begin{array}{l}\text { Cyclic dodecapeptide (OaDode, ovine } \\
37 \text { cathelicidin, sheep, ruminant, } \\
\text { animals) }\end{array}$ & RICRIIFLRVCR & 12.00 & 0.36 & & {$[49]$} \\
\hline $\begin{array}{l}\text { Bactenecin (cyclic dodecapeptide, } \\
\text { bovine cathelicidin, cow, cattle, } \\
\text { ruminant, animals; BBMm; JJsn; } \\
\text { derivatives: Bac2A) }\end{array}$ & RLCRIVVIRVCR & 12.00 & 0.33 & & {$[50]$} \\
\hline $\begin{array}{l}\text { RL-37 (RL37, cathelicidin, Old World } \\
\text { monkey, primates, animals) }\end{array}$ & RLGNFFRKVKEKIGGGLKKVGQKIKDFLGNLVPRTAS & 11.90 & 0.59 & & {$[51]$} \\
\hline $\begin{array}{l}\text { BACTENECIN } 7 \text { (bac-7, bac 7; bac7; } \\
40 \text { Pro-rich; cow cathelicidin, ruminant, } \\
\text { animals; BBL, SeqAR, BBPP) }\end{array}$ & $\begin{array}{l}\text { RRIRPRPPRLPRPRPRPLPFPRPGPRPIPRPLPFPRPGPRPI- } \\
\text { PRPLPFPRPGPRPIPRPL }\end{array}$ & 13.20 & 0.25 & & {$[52]$} \\
\hline $\begin{array}{l}\text { Bac4 (Pro-rich, Arg-rich; cow } \\
\text { cathelicidin, ruminant, animals) }\end{array}$ & RRLHPQHQRFPRERPWPKPLSLPLPRPGPRPWPKPL & 12.90 & 0.23 & & {$[53]$} \\
\hline $\begin{array}{l}\text { Hyphancin IIIE (insects, invertebrates, } \\
\text { animals) }\end{array}$ & RWKFFKKIERVGQNVRDGLIKAGPAIQVLGAAKAL & 11.80 & 0.41 & & {$[54]$} \\
\hline $\begin{array}{l}\text { Cecropin B (insects, invertebrates, } \\
\text { animals) }\end{array}$ & RWKIFKKIEKMGRNIRDGIVKAGPAIEVLGSAKAI & 11.40 & 0.42 & & {$[55]$} \\
\hline $\begin{array}{l}\text { Hyphancin IIID (insects, invertebrates, } \\
\text { animals) }\end{array}$ & RWKIFKKIERVGQNVRDGIIKAGPAIQVLGTAKAL & 11.80 & 0.41 & & {$[54]$} \\
\hline $\begin{array}{l}\text { Hyphancin IIIG (insects, invertebrates, } \\
\text { animals) }\end{array}$ & RWKVFKKIEKVGRHIRDGVIKAGPAITVVGQATAL & 11.80 & 0.38 & & [54] \\
\hline
\end{tabular}


TABle 4: Continued.

\begin{tabular}{|c|c|c|c|c|c|c|}
\hline No. & Peptide & Sequence & IP & $\mathrm{HM}$ & Status & Reference \\
\hline 46 & $\begin{array}{l}\text { Hyphancin IIIF (insects, invertebrates, } \\
\text { animals) }\end{array}$ & RWKVFKKIEKVGRNIRDGVIKAGPAIAVVGQAKAL & 11.80 & 0.39 & & [54] \\
\hline 47 & $\begin{array}{l}\text { Phylloseptin-H4 (Phylloseptin-6, } \\
\text { PLS-H4, PS-6, XXA, frog, amphibians, } \\
\text { animals) }\end{array}$ & SLIPHAINAVSAIAKHF & 9.65 & 0.47 & & [29] \\
\hline 48 & $\begin{array}{l}\text { Pep5 (Lantibiotic, type 1, class } 1 \\
\text { bacteriocin, Gram-positive bacteria; } \\
\text { XXT3; XXW3) }\end{array}$ & TAGPAIRASVKQCQKTLKATRLFTVSCKGKNGCK & 11.10 & 0.27 & & [56] \\
\hline 49 & $\begin{array}{l}\text { Clavanin C (sea squirt, tunicate, } \\
\text { invertebrates, animals) }\end{array}$ & VFHLLGKIIHHVGNFVYGFSHVF & 9.55 & 0.47 & & [21] \\
\hline 50 & $\begin{array}{l}\text { Andropin (insects, invertebrates, } \\
\text { animals) }\end{array}$ & VFIDILDKVENAIHNAAQVGIGFAKPFEKLINPK & 7.50 & 0.45 & $\mathrm{X}$ & [57] \\
\hline 51 & $\begin{array}{l}\text { Clavanin A (urochordates, sea squirts, } \\
\text { and sea pork, tunicate, invertebrates, } \\
\text { animals) }\end{array}$ & VFQFLGKIIHHVGNFVHGFSHVF & 9.71 & 0.61 & & [21] \\
\hline
\end{tabular}

IP and HM parameters were calculated and 46 of them are in the ranges previously mentioned in Section 2.1 ; that is, IP = 9.65-11.80 and $\mathrm{HM}=0.16-0.57$.

The APD database information integrity verification [11] showed 14 peptides not classified yet. When their activity as SCAAP was double checked by the polarity index method, there was a mismatch. The APD database margin of error did not exceed $8 \%$.

\section{Discussion}

All different peptide classifications achieved over the decades seem to be directed to validate the peptide action and toxicity. However, it appears that these two characteristics are intrinsically related to the space where the peptide interacts as well as to the structural form of the subject membrane. Missing peptide specificity in the studied isolated peptides indicates that nature avoids peptide specificity in order not to favor certain pathogen agents in their blocking action.

Most peptides found experimentally show multiple actions on pathogen agents. Thus it appears that the detection and prediction of antibacterial peptides-in our case SCAAP-is more related to general, nonspecific peptide profiles that are well known for their antibacterial action. For that reason and as given in the present case, more efficient algorithms should rather evaluate fundamental characteristics of such peptides and search for small differences among them.

The design of bioinformatical algorithms to detect antimicrobial peptides is basically of two types.

(i) Based on a system of differential equations [15] that characterizes the peptide properties with an exponentially growing complexity.

(ii) The inclusion of multiple peptide characteristics without affecting its complexity [16] where the efficiency greatly depends on a skillful peptide set selection.
Our polarity index method falls in the latter category and is characterized by the following.

(i) Effectively excluding multiple action peptides, with a margin of error less than $10 \%$ and single-action peptides with a margin of error less than $6 \%$.

(ii) Its efficiency to identify SCAAP subjects which is higher than $90 \%$.

(iii) The simplicity of the computational method which is easy to implement for massive parallel processing in GPUs [17].

(iv) Its straightforwardness by measuring the peptide polarity exclusively and from this information effectively classifying its pathogenic action.

The algorithm involved in this method allows simple modifications to identify in a general level peptide groups by their pathogenic action and in a more specific level to refine the peptide search and identification as in the group used here.

The polarity index method uses the amino acid polarity classification; however there are other types of classifications $[18,19]$ that use the amino acid side chain chemical properties such as the neutral $\mathrm{pH}$ charge, their type of chemical structure, the reactivity, the elements present, or the ability to form hydrogen bonds. These classifications can be used to generate a more specific peptide blueprint when searched, with features that would not be considered otherwise.

As this method is a simple mathematical and computational algorithm, it does not demand heavy computational resources as processing memory or speed; therefore it can be used to explore peptide regions. These peptide regions can be worked out by evaluating massively all possible peptide combinations with the same length [20], thus taking advantage of the polarity index method simplicity to determine their activity. 


\section{Conclusion}

The statistical/computacional polarity index method is an effective algorithm to find potential antibacterial peptides from a public domain database. These peptides have been denominated "Selective Cationic Amphipathic Antibacterial Peptides" (SCAAP). The method features a high efficiency to exclude peptides that exhibit single pathogenic action on other pathogens than bacteria, and it is equally efficient to exclude multiple-action peptides. In summary, the polarity index method is an adaptable and efficient method to detect and predict SCAAPs and it is a useful analysis and modeling tool for biological sequences using a single physicochemical property.

\section{Availability}

The polarity index computational implementation is listed in the Appendix section.

\section{Appendix}

\section{Source Program for the Detection of SCAAP by the Polarity Index Method}

c Author Carlos Polanco 2011.

C

c Program Detection of SCAAP by Polarity-index method.

C

c Execution: ./a.out AEVAPAPAAAAPAKAPKKKAAAKPKKAGPS

c

c

implicit none

character $* 1$ arreglo(100), arreglo3(500)

character $* 500$ backup

character $* 1$ convert

integer convertN, tipo2

integer base(16), candidato(16), aciertos2, aciertos0

integer aciertost, aciertos3, aciertos4, aciertos14, aciertos 24

integer aciertos34, aciertos44, aciertos04, aciertos1, aciertos5

integer $\mathrm{x} 1, \mathrm{x} 2, \mathrm{x} 3, \mathrm{x} 4, n, j, i, k$

real tipo 1 real comodin

double precision matriz $(4,4)$

double precision total, peso $(4,4)$

equivalence (arreglo3, backup)

open $(2$, file $=$ "candidate 0. dat" $)$

34 format (f8.4, 1x, I2)

52 format (A3)

c Relative frequency position of pairs of amino acid in the

c candidate SCAAP

c

peso $(4,4)=0.272727281 / 0.272727281$

peso $(1,4)=0.209790215 / 0.272727281$

peso $(4,1)=0.164335668 / 0.272727281$

peso $(1,1)=0.087412588 / 0.272727281$

peso $(4,3)=0.083916083 / 0.272727281$

peso $(3,3)=0.062937066 / 0.272727281$

peso $(3,4)=0.059440561 / 0.272727281$

peso $(3,1)=0.024475524 / 0.272727281$

peso $(2,1)=0.006993007 / 0.272727281$

peso $(1,3)=0.006993007 / 0.272727281$

peso $(4,2)=0.006993007 / 0.272727281$

peso $(2,4)=0.003496503 / 0.272727281$

peso $(2,3)=0.003496503 / 0.272727281$

peso $(1,2)=0.003496503 / 0.272727281$

peso $(3,2)=0.003496503 / 0.272727281$

peso $(2,2)=0.000000000 / 0.272727281$

c Position of pairs of amino acid in the candidate SCAAP

C

$$
\begin{aligned}
& \operatorname{base}(1)=16 \\
& \operatorname{base}(2)=4 \\
& \operatorname{base}(3)=13 \\
& \operatorname{base}(4)=15 \\
& \operatorname{base}(5)=12 \\
& \operatorname{base}(6)=1 \\
& \operatorname{base}(7)=11 \\
& \operatorname{base}(8)=9 \\
& \operatorname{base}(9)=3 \\
& \operatorname{base}(10)=14 \\
& \operatorname{base}(11)=6 \\
& \operatorname{base}(12)=8 \\
& \operatorname{base}(13)=2 \\
& \operatorname{base}(14)=7
\end{aligned}
$$




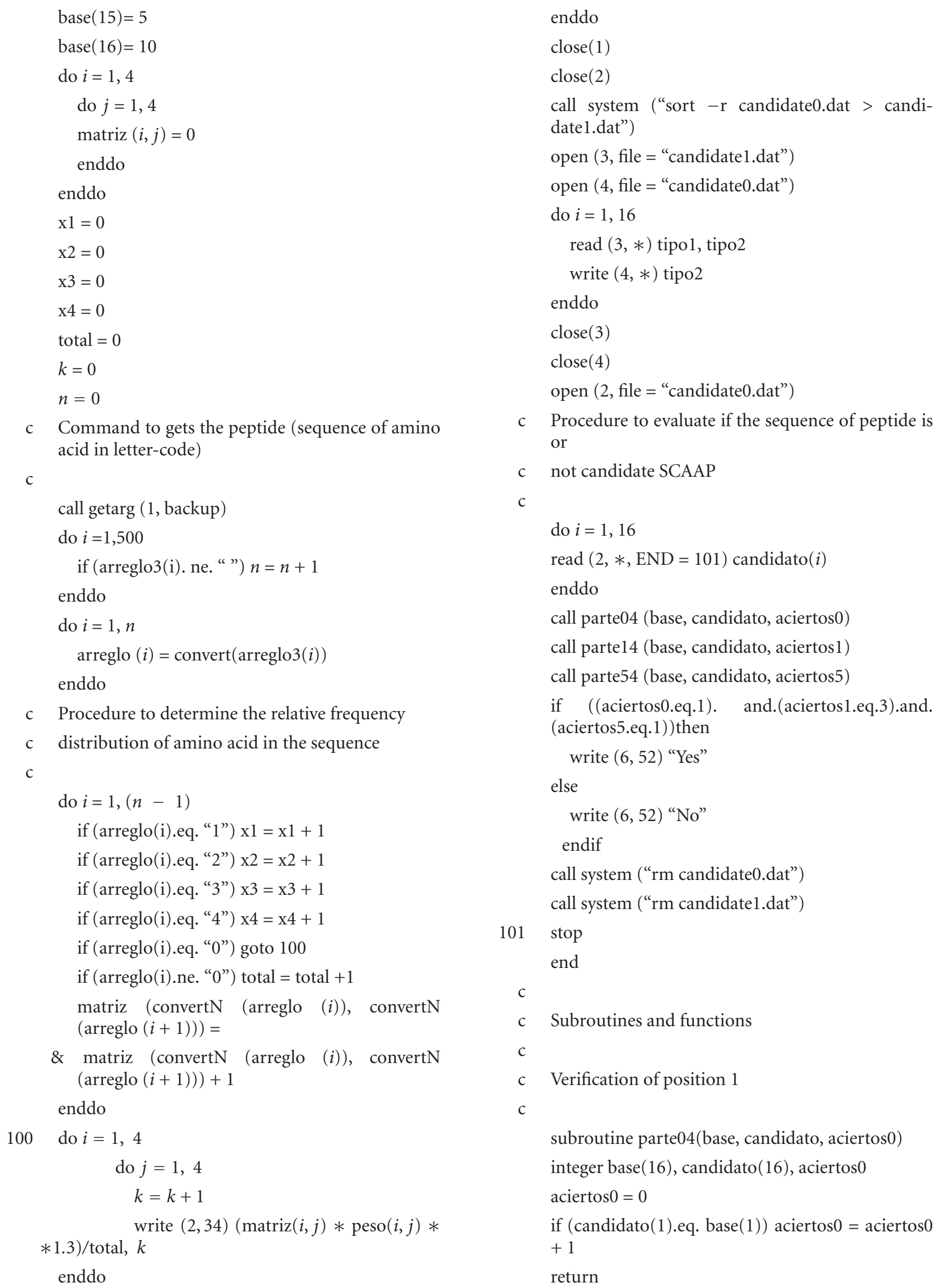


end

subroutine parte14(base, candidato, aciertos1)

integer base(16), candidato(16), aciertos1

aciertos $1=0$

do $i=2,4$

if $(\operatorname{candidato}(i)$.eq. base $(i))$ aciertos $1=$ aciertos $1+1$

enddo

return

end

subroutine parte54 (base, candidato, aciertos5)

integer base(16), candidato(16), aciertos5

aciertos $5=0$

if (candidato(16).eq. base(16)) aciertos5 = aciertos $5+1$

return

end

C

$$
\begin{aligned}
& \text { character function convert(tipo) } \\
& \text { character } * 1 \text { tipo } \\
& \text { if (tipo.eq. "A") convert }=\text { " } 4 \text { " } \\
& \text { if (tipo.eq. "C") convert = " } 3 \text { " } \\
& \text { if }(\text { tipo.eq. "D") convert = " } 2 \text { " } \\
& \text { if (tipo.eq. "E”) convert = "2" } \\
& \text { if (tipo.eq. "F") convert }=\text { "4" } \\
& \text { if (tipo.eq. "G") convert = " } 3 \text { " } \\
& \text { if (tipo.eq. "H") convert = " } 1 \text { " } \\
& \text { if (tipo.eq. "I") convert = "4" } \\
& \text { if (tipo.eq. "K") convert = " } 1 \text { " } \\
& \text { if (tipo.eq. "L") convert = "4" } \\
& \text { if (tipo.eq. "M") convert = "4" } \\
& \text { if (tipo.eq. "N") convert }=\text { " } 3 \text { " } \\
& \text { if }(\text { tipo.eq. "P") convert }=\text { " } 4 \text { " } \\
& \text { if (tipo.eq. "Q") convert = “ } 3 \text { " } \\
& \text { if }(\text { tipo.eq. " } R \text { ") convert }=\text { " } 1 \text { " } \\
& \text { if (tipo.eq. "S") convert }=\text { " } 3 \text { " } \\
& \text { if (tipo.eq. "T") convert }=\text { " } 3 \text { " } \\
& \text { if (tipo.eq. "V") convert = " } 4 \text { " } \\
& \text { if (tipo.eq. "W") convert = "4" }
\end{aligned}
$$

if (tipo.eq. "Y") convert = "2"

if (tipo.eq. "X") convert = "0"

return

end

c Conversion number in code-letters to numbers in code-numbers

c

$$
\begin{aligned}
& \text { integer function convertN(tipo) } \\
& \text { character } * 1 \text { tipo } \\
& \text { if (tipo.eq. "1") convertN }=1 \\
& \text { if (tipo.eq. "2") convertN }=2 \\
& \text { if (tipo.eq. " } 3 \text { ") convertN }=3 \\
& \text { if (tipo.eq. " } 4 \text { ") convertN }=4 \\
& \text { return } \\
& \text { end }
\end{aligned}
$$

\section{Conflicts of Interest}

We declare that we do not have any financial and personal relationship with other people or organizations that could inappropriately influence (bias) our work.

\section{Authors Contribution}

Experiments conception and design were done by C. Polanco and J. L. Samaniego. Experimental performance was made by C. Polanco. Data analysis was made by T. Buhse. Results discussion was made by: T. Buhse, F. G. Mosqueira, A. NegronMendoza, S. Ramos-Bernal, and J. A. Castanon-Gonzalez.

\section{Acknowledgments}

The authors acknowledge the support given by the Departamento de Computo and the Instituto de Ciencias Nucleares, Universidad Nacional Autonoma de México, and by Concepcion Celis Juarez for proofreading the paper.

\section{References}

[1] T. Unger, Z. Oren, and Y. Shai, "The effect of cyclization of magainin 2 and melittin analogues on structure, function, and model membrane interactions: implication to their mode of action," Biochemistry, vol. 40, no. 21, pp. 6388-6397, 2001.

[2] M. R. Yeaman and N. Y. Yount, "Mechanisms of antimicrobial peptide action and resistance," Pharmacological Reviews, vol. 55, no. 1, pp. 27-55, 2003.

[3] H. G. Boman, "Peptide antibiotics and their role in innate immunity," Annual Review of Immunology, vol. 13, pp. 61-92, 1995.

[4] J. M. Saugar, M. J. Rodríguez-Hernández, B. G. De La Torre et al., "Activity of cecropin A-melittin hybrid peptides against colistin-resistant clinical strains of Acinetobacter baumannii: molecular basis for the differential mechanisms of action," Antimicrobial Agents and Chemotherapy, vol. 50, no. 4, pp. 1251-1256, 2006. 
[5] Y. Cao, R. Q. Yu, Y. Liu et al., "Design, recombinant expression, and antibacterial activity of the cecropins-melittin hybrid antimicrobial peptides," Current Microbiology, vol. 61, no. 3, pp. 169-175, 2010.

[6] L. Z. Wan, Y. Park, I. S. Park et al., "Improvement of bacterial cell selectivity of melittin by a single Trp mutation with a peptoid residue," Protein and Peptide Letters, vol. 13, no. 7, pp. 719-725, 2006.

[7] G. Del Rio, S. Castro-Obregon, R. Rao, H. M. Ellerby, and D. E. Bredesen, "APAP, a sequence-pattern recognition approach identifies substance $\mathrm{P}$ as a potential apoptotic peptide," FEBS Letters, vol. 494, no. 3, pp. 213-219, 2001.

[8] H. M. Ellerby, W. Arap, L. M. Ellerby et al., "Anti-cancer activity of targeted pro-apoptotic peptides," Nature Medicine, vol. 5, no. 9, pp. 1032-1038, 1999.

[9] S. Y. Shin, J. H. Kang, S. Y. Jang, Y. Kim, K. L. Kim, and K. S. Hahm, "Effects of the hinge region of cecropin A(18)-magainin 2(1-12), a synthetic antimicrobial peptide, on liposomes, bacterial and tumor cells," Biochimica et Biophysica Acta, vol. 1463, no. 2, pp. 209-218, 2000.

[10] R. E. Hausman and G. M. Cooper, The Cell: A Molecular Approach, ASM Press, Washington, DC, USA, 2004.

[11] G. Wang, X. Li, and Z. Wang, "APD2: the updated antimicrobial peptide database and its application in peptide design," Nucleic Acids Research, vol. 37, no. 1, pp. D933-D937, 2009.

[12] K. Iwai and T. Ando, "N $\rightarrow$ O acyl rearrangement," Methods in Enzymology, vol. 11, pp. 263-282, 1967.

[13] C. Polanco and J. L. Samaniego, "Detection of selective cationic amphipatic antibacterial peptides by Hidden Markov models," Acta Biochimica Polonica, vol. 56, no. 1, pp. 167-176, 2009.

[14] D. Eisenberg, R. M. Weiss, T. C. Terwilliger, and W. Wilcox, "Hydrophobic moments and protein structure," Faraday Symposia of the Chemical Society, vol. 17, pp. 109-120, 1982.

[15] E. L. Ince, Ordinary Differential Equations, Dover, New York, NY, USA, 1956.

[16] B. Resch, "Hidden Markov Models. A tutorial for the course computational intelligence. Signal processing and speech communication laboratory," 2004, http://speech.tifr.res.in/ tutorials/hmmTutExamplesAlgo.pdf.

[17] W. M. W. Hwu, GPU Computing Gems Emerald Edition, Elsevier, New York, NY, USA, 2011.

[18] J. Davies and B. Shaffer Littlewood, Elementary BiochemistryAn Introduction to the Chemistry of Living Cells, Prentice Hall, Upper Saddle River, NJ, USA, 1979.

[19] The Australian Naturopathic Network, 1998-2002, http:// www.ann.com.au/MedSci/amino.htm.

[20] C. Polanco González, M. A. Nuño Maganda, M. Arias-Estrada, and G. del Rio, "An FPGA implementation to detect selective cationic antibacterial peptides," PloS one, vol. 6, no. 6, article e21399, 2011.

[21] I. H. Lee, C. Zhao, Y. Cho, S. S. L. Harwig, E. L. Cooper, and R. I. Lehrer, "Clavanins, $\alpha$-helical antimicrobial peptides from tunicate hemocytes," FEBS Letters, vol. 400, no. 2, pp. 158-162, 1997.

[22] Y. J. Basir, F. C. Knoop, J. Dulka, and J. M. Conlon, "Multiple antimicrobial peptides and peptides related to bradykinin and neuromedin $\mathrm{N}$ isolated from skin secretions of the pickerel frog, Rana palustris," Biochimica et Biophysica Acta, vol. 1543, no. 1, pp. 95-105, 2000.

[23] J. M. Conlon, M. Mechkarska, E. Ahmed et al., "Host defense peptides in skin secretions of the Oregon spotted frog Rana pretiosa: implications for species resistance to chytridiomycosis," Developmental and Comparative Immunology, vol. 35, no. 6, pp. 644-649, 2011.

[24] J. Goraya, Y. Wang, Z. Li et al., "Peptides with antimicrobial activity from four different families isolated from the skins of the North American frogs Rana luteiventris, Rana berlandieri and Rana pipiens," European Journal of Biochemistry, vol. 267, no. 3, pp. 894-900, 2000.

[25] J. M. Conlon, J. Kolodziejek, N. Nowotny et al., "Characterization of antimicrobial peptides from the skin secretions of the Malaysian frogs, Odorrana hosii and Hylarana picturata (Anura:Ranidae)," Toxicon, vol. 52, no. 3, pp. 465-473, 2008.

[26] J. Goraya, F. C. Knoop, and J. M. Conlon, "Ranatuerins: antimicrobial peptides isolated from the skin of the American bullfrog, Rana catesbeiana," Biochemical and Biophysical Research Communications, vol. 250, no. 3, pp. 589-592, 1998.

[27] A. H. Thompson, A. J. Bjourson, D. F. Orr, C. Shaw, and S. McClean, "A combined mass spectrometric and cDNA sequencing approach to the isolation and characterization of novel antimicrobial peptides from the skin secretions of Phyllomedusa hypochondrialis azurea," Peptides, vol. 28, no. 7, pp. 1331-1343, 2007.

[28] K. Conceição, K. Konno, M. Richardson et al., "Isolation and biochemical characterization of peptides presenting antimicrobial activity from the skin of Phyllomedusa hypochondrialis," Peptides, vol. 27, no. 12, pp. 3092-3099, 2006.

[29] J. R. S. A. Leite, L. P. Silva, M. I. S. Rodrigues et al., "Phylloseptins: a novel class of anti-bacterial and anti-protozoan peptides from the Phyllomedusa genus," Peptides, vol. 26, no. 4, pp. 565-573, 2005.

[30] D. Vanhoye, F. Bruston, S. El Amri, A. Ladram, M. Amiche, and P. Nicolas, "Membrane association, electrostatic sequestration, and cytotoxicity of Gly-Leu-rich peptide orthologs with differing functions," Biochemistry, vol. 43, no. 26, pp. 8391-8409, 2004.

[31] R. Galinier, E. Roger, P. E. Sautiere, A. Aumelas, B. Banaigs, and G. Mitta, "Halocyntin and papillosin, two new antimicrobial peptides isolated from hemocytes of the solitary tunicate, Halocynthia papillosa," Journal of Peptide Science, vol. 15, no. 1, pp. 48-55, 2009.

[32] R. C. Anderson, Antimicrobial peptides isolate from ovine blood neutrophils, thesis, Massey University, Palmerston, North New Zealand, 2005.

[33] M. J. Maclean, C. S. Brinkworth, D. Bilusich et al., "New caerin antibiotic peptides from the skin secretion of the Dainty Green Tree Frog Litoria gracilenta. Identification using positive and negative ion electrospray mass spectrometry," Toxicon, vol. 47, no. 6, pp. 664-675, 2006.

[34] R. J. Jackway, J. H. Bowie, D. Bilusich et al., "The fallaxidin peptides from the skin secretion of the Eastern Dwarf Tree Frog Litoria fallax. Sequence determination by positive and negative ion electrospray mass spectrometry: antimicrobial activity and cDNA cloning of the fallaxidins," Rapid Communications in Mass Spectrometry, vol. 22, no. 20, pp. 3207-3216, 2008.

[35] K. L. Wegener, C. S. Brinkworth, J. H. Bowie, J. C. Wallace, and M. J. Tyler, "Bioactive dahlein peptides from the skin secretions of the Australian aquatic frog Litoria dahlii: sequence determination by electrospray mass spectrometry," Rapid Communications in Mass Spectrometry, vol. 15, no. 18, pp. 1726-1734, 2001.

[36] D. J. M. Stone, R. J. Waugh, J. H. Bowie, J. C. Wallace, and M. J. Tyler, "Peptides from Australian frogs. Structures of 
the caeridins from Litoria caerulea," Journal of the Chemical Society, Perkin Transactions 1, no. 5, pp. 573-576, 1993.

[37] E. Iwakoshi-Ukena, G. Okada, A. Okimoto, T. Fujii, M. Sumida, and K. Ukena, "Identification and structure-activity relationship of an antimicrobial peptide of the palustrin-2 family isolated from the skin of the endangered frog Odorrana ishikawae," Peptides, vol. 32, no. 10, pp. 2052-2057, 2011.

[38] K. S. Moore, C. L. Bevins, M. M. Brasseur et al., "Antimicrobial peptides in the stomach of Xenopus laevis," Journal of Biological Chemistry, vol. 266, no. 29, pp. 19851-19857, 1991.

[39] A. M. Cole, P. Weis, and G. Diamond, "Isolation and characterization of pleurocidin, an antimicrobial peptide in the skin secretions of winter flounder," Journal of Biological Chemistry, vol. 272, no. 18, pp. 12008-12013, 1997.

[40] N. Boulanger, R. Brun, L. Ehret-Sabatier, C. Kunz, and P. Bulet, "Immunopeptides in the defense reactions of Glossina morsitans to bacterial and Trypanosoma brucei brucei infections," Insect Biochemistry and Molecular Biology, vol. 32, no. 4, pp. 369-375, 2002.

[41] V. Čeřovský, J. Slaninová, V. Fučík et al., "New potent antimicrobial peptides from the venom of Polistinae wasps and their analogs," Peptides, vol. 29, no. 6, pp. 992-1003, 2008.

[42] S. M. Yoe, C. S. Kang, S. S. Han, and I. S. Bang, "Characterization and cDNA cloning of hinnavin II, a cecropin family antibacterial peptide from the cabbage butterfly, Artogeia rapae," Comparative Biochemistry and Physiology B, vol. 144, no. 2, pp. 199-205, 2006.

[43] P. L. Yu, S. D. Choudhury, and K. Ahrens, "Purification and characterization of the antimicrobial peptide, ostricacin," Biotechnology Letters, vol. 23, no. 3, pp. 207-210, 2001.

[44] C. Zhao, L. Liaw, I. Hee Lee, and R. I. Lehrer, "cDNA cloning of Clavanins: antimicrobial peptides of tunicate hemocytes," FEBS Letters, vol. 410, no. 2-3, pp. 490-492, 1997.

[45] L. M. Cintas, P. Casaus, C. Herranz et al., "Biochemical and genetic evidence that Enterococcus faecium L50 produces enterocins L50A and L50B, the sec-dependent enterocin p, and a novel bacteriocin secreted without an $\mathrm{N}$-terminal extension termed enterocin Q," Journal of Bacteriology, vol. 182, no. 23, pp. 6806-6814, 2000.

[46] M. E. Selsted, Y. Q. Tang, W. L. Morris et al., "Purification, primary structures, and antibacterial activities of $\beta$-defensins, a new family of antimicrobial peptides from bovine neutrophils," Journal of Biological Chemistry, vol. 268, no. 9, pp. 6641-6648, 1993.

[47] H. P. Jia, S. A. Wowk, B. C. Schutte et al., "A novel murine $\beta$-defensin expressed in tongue, esophagus, and trachea $*$," Journal of Biological Chemistry, vol. 275, no. 43, pp. 3331433320, 2000.

[48] O. Shamova, K. A. Brogden, C. Zhao, T. Nguyen, V. N. Kokryakov, and R. I. Lehrer, "Purification and properties of prolinerich antimicrobial peptides from sheep and goat leukocytes," Infection and Immunity, vol. 67, no. 8, pp. 4106-4111, 1999.

[49] L. Bagella, M. Scocchi, and M. Zanetti, "cDNA sequences of three sheep myeloid cathelicidins," FEBS Letters, vol. 376, no. 3, pp. 225-228, 1995.

[50] D. Romeo, B. Skerlavaj, M. Bolognesi, and R. Gennaro, "Structure and bactericidal activity of an antibiotic dodecapeptide purified from bovine neutrophils," Journal of Biological Chemistry, vol. 263, no. 20, pp. 9573-9575, 1988.

[51] I. Zelezetsky, A. Pontillo, L. Puzzi et al., "Evolution of the primate cathelicidin: correlation between structural variations and antimicrobial activity," Journal of Biological Chemistry, vol. 281, no. 29, pp. 19861-19871, 2006.
[52] P. Storici, A. Tossi, B. Lenarčič and D. Romeo, "Purification and structural characterization of bovine cathelicidins, precursors of antimicrobial peptides," European Journal of Biochemistry, vol. 238, no. 3, pp. 769-776, 1996.

[53] R. C. Anderson and P. L. Yu, "Isolation and characterisation of proline/arginine-rich cathelicidin peptides from ovine neutrophils," Biochemical and Biophysical Research Communications, vol. 312, no. 4, pp. 1139-1146, 2003.

[54] S. S. Park, S. W. Shin, M. K. Kim, D. S. Park, H. W. Oh, and H. Y. Park, "Differences in the skin peptides of the male and female Australian tree frog Litoria splendida: the discovery of the aquatic male sex pheromone splendipherin, together with Phe8 caerulein and a new antibiotic peptide caerin 1.10," European Journal of Biochemistry, vol. 267, no. 1, pp. 269-275, 2000.

[55] I. Morishima, S. Suginaka, T. Ueno, and H. Hirano, "Isolation and structure of cecropins, inducible antibacterial peptides, from the silkworm Bombyx mori," Comparative Biochemistry and Physiology B, vol. 95, no. 3, pp. 551-554, 1990.

[56] C. Kaletta, K. D. Entian, R. Kellner, G. Jung, M. Reis, and H. G. Sahl, "Pep5, a new lantibiotic: structural gene isolation and prepeptide sequence," Archives of Microbiology, vol. 152, no. 1, pp. 16-19, 1989.

[57] C. Samakovlis, P. Kylsten, D. A. Kimbrell, A. Engstrom, and D. Hultmark, "The Andropin gene and its product, a malespecific antibacterial peptide in Drosophila melanogaster," EMBO Journal, vol. 10, no. 1, pp. 163-169, 1991. 

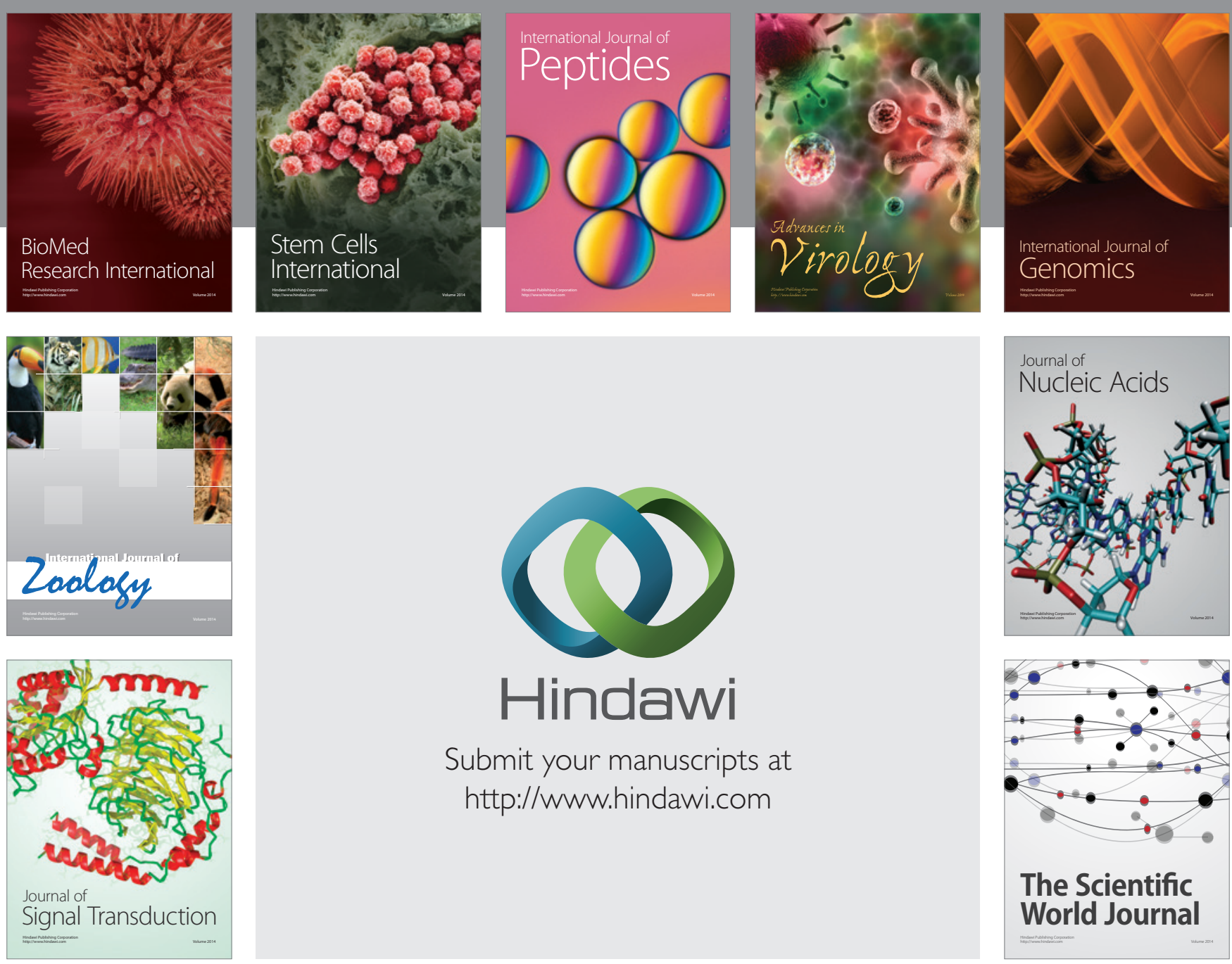

Submit your manuscripts at

http://www.hindawi.com
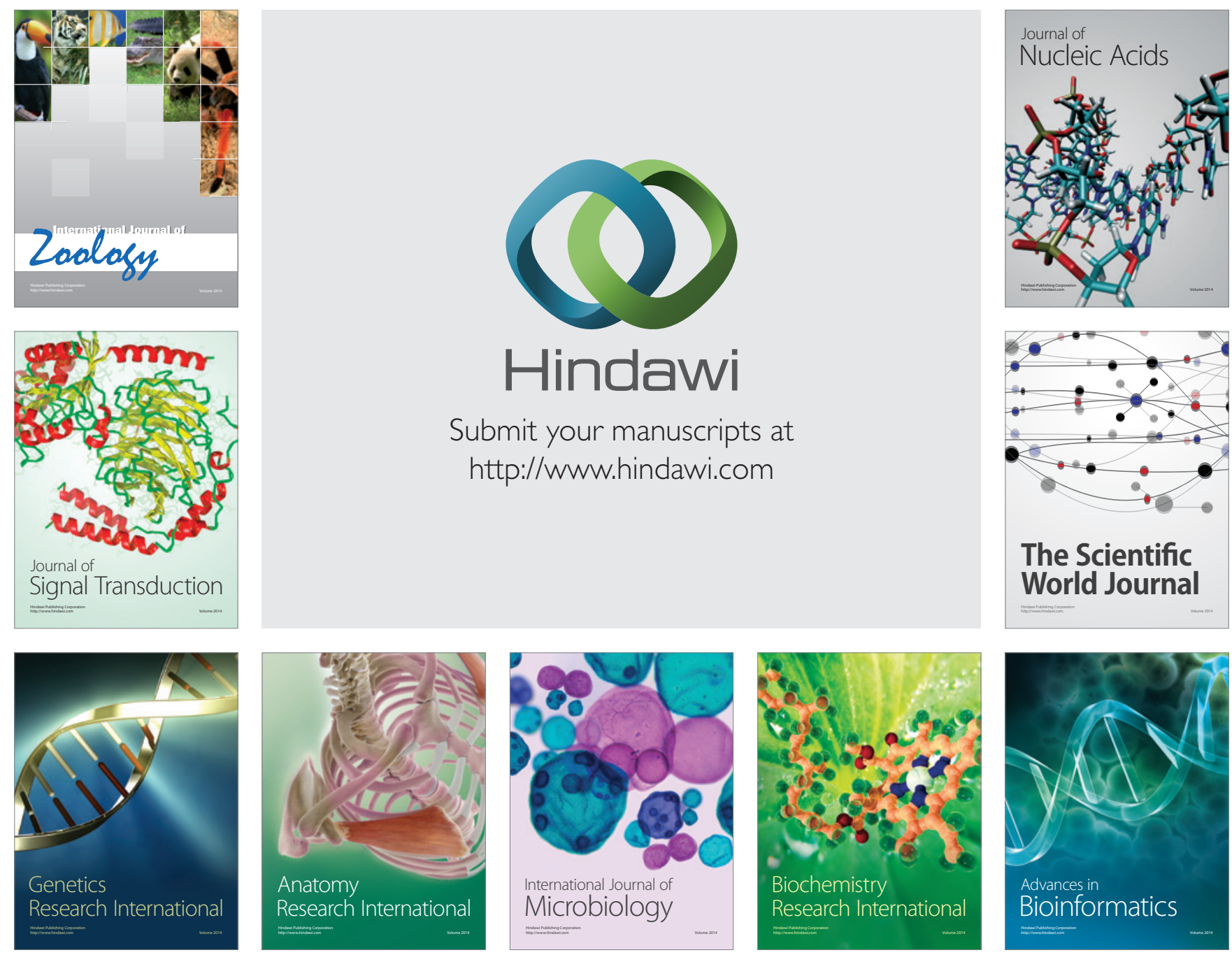

The Scientific World Journal
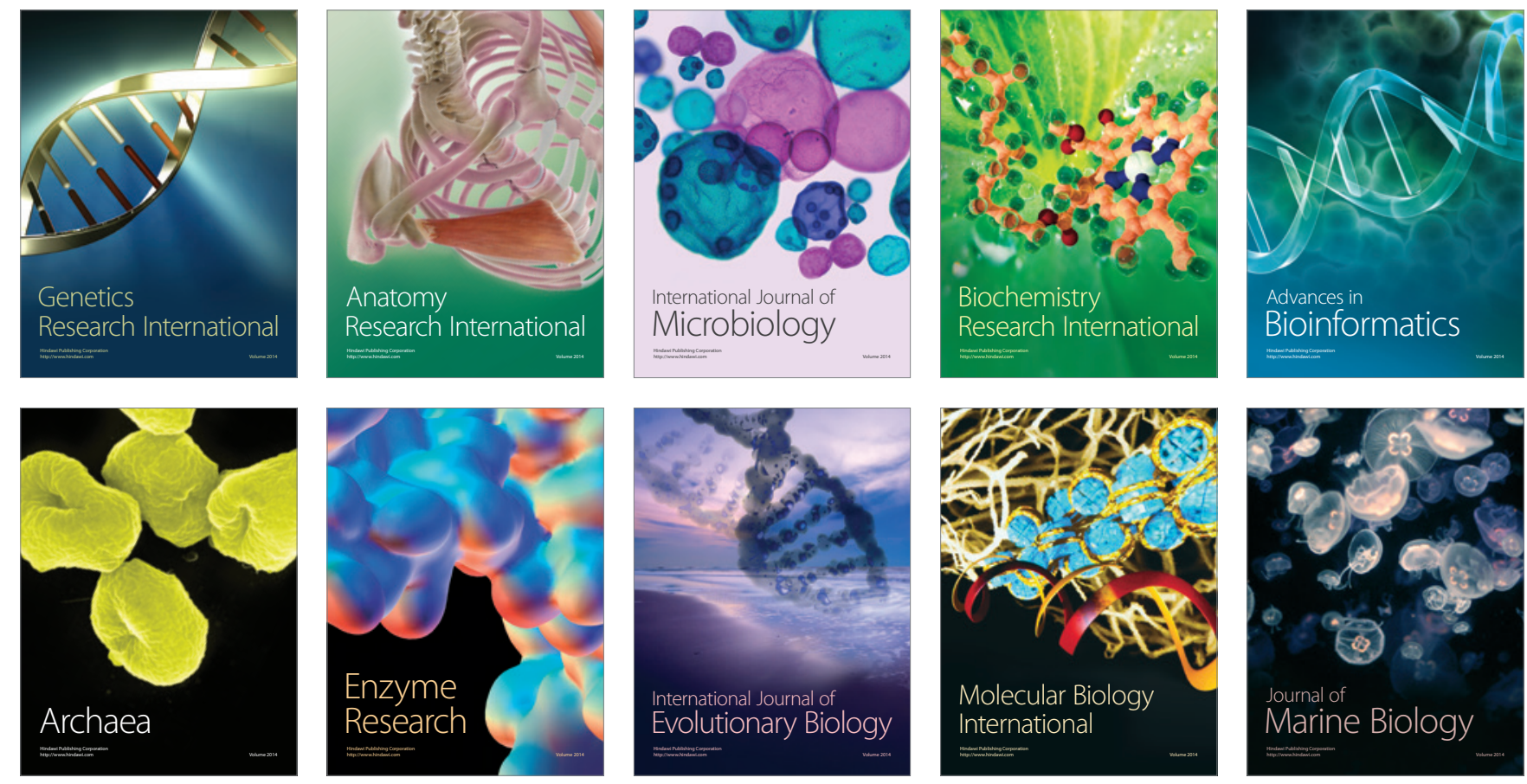